\title{
Authentication of Dog Fat With Gas Chromatography-Mass Spectroscopy Combined With Chemometrics
}

\author{
Any Guntarti \\ Correspondence: University of Ahmad Dahlan, Indonesia. E-mail: any_guntarti@yahoo.co.id
}

Received: October 9, 2018 Accepted: November 1, 2018 Online Published: November 28, 2018

doi:10.5539/ijc.v10n4p124

URL: https://doi.org/10.5539/ijc.v10n4p124

\begin{abstract}
Indonesia is a country with a majority of Muslim population. As a Muslim majority country, providing halal products becomes a liability. The problem that has received a lot of attention right now is the concern that contamination of food products by meat, one of them is dog meat. The purpose of this study was to authenticate dog fat by using Gas Chromatography-Mass Spectrophotometry (GC-MS)combined with chemometrics.

Dogs that used in the study were taken from Bantul, Yogyakarta. Dog snacks were heated in an oven at $90-100^{\circ} \mathrm{C}$ for approximately one hour. Oils / fats obtained from derivatization process was carried out by using $\mathrm{NaOCH}_{3}$ and $\mathrm{BF}_{3}$. The methyl ester compound was injected into the GC-MS instrument system.

The Results of this study was dog fat that analyzed by GC-MS contains 9 types of fatty acids, namely: lauric $(1.19 \pm$ $0.25) \%$, myristate $(4.33 \pm 0.30) \%$, pentadekanoate $(0.12 \pm 0.02) \%$, palmitoleate $(4.60 \pm 0.07) \%$, palmitate $(12.80 \pm$ $2.90) \%$, margarate $(0.13 \pm 0.09) \%$, oleate $(44,33 \pm 5.22) \%$, stearic $(14.71 \pm 0.32) \%$, and arachidonic $(1.29 \pm 0.11) \%$. Total content of fatty acids in dogs was $50.22 \%$ and saturated fatty acids were $33.03 \%$. Chemometric grouping with the Principles Component Analysis (PCA) shows that dog fat is very close to lard. The fatty acids that contained in dog fat can be used to authenticate dog meat.
\end{abstract}

Keywords: chemometrics, dog fatty acid, GC-MS, PCA

\section{Introduction}

Along with rising incomes lead to demand for meat consumption in various regions of Indonesia have increased. Increased consumption of meat in Indonesia not only includes halal meat such as beef but also non-halal meat such as dog meat which in some areas is a local food that is in great demand by the public (Rahayu, et al., 2018). This can be seen from the number of processed dog meat vendors that are provided every week for slaughter.

Currently falsification with halal meat using dog meat is quite profitable since the trade in wild dogs in several countries is carried out at cheap prices (Guntarti and Pratiwi, 2017; Rahman et al., 2014). As in the case, the discovery of processed beef product counterfeiting by using dog meat in Bandung Raya. The Criminal Investigation Unit of Pameungpeuk Police of Bandung Police managed to dismantle the dog meat sales network that had been troubling the public. Based on the investigation, the dog meats that have been slaughtered then processed into various types of food including meatballs, rendang and sausages then sold in various restaurants in Bandung (Guntarti et al., 2015).

One common technique used for oil characterization is gas chromatography. It also can be used for food analysis for the determination of antioxidants, food additives, dairy products, contaminants, and food counterfeiters (Grob, 2004). GC-MS can analyze quickly, high capacity, sensitive and can be combined with various other methods, including mass spectrometry (Park and Lee, 2003). Because of its separation characteristics, chromatographic techniques had been widely developed and used in the analysis of non-halal components in food products (Rohman and Che Man, 2011b). The selection of detectors is important. The detector is an electronic sensor that converts the signal of the carrier gas and the components in it into electronic signals (Flores et al., 2006). Various detectors have been used for the analysis of pork fat components particularly the fatty acid composition analysis. The detector that commonly used was flame ionization detector (FID) or a mass spectrometer detector whose combined with gas chromatograph called gas chromatography-mass spectrometry (GC-MS) (Grob, 2004). The FID detector is the most universal detector for organic compounds (Kealey and Haines, 2002).

GC applications are for the analysis of compounds that are heat-stable and quite volatile. The approach taken for the analysis of fatty acids in the oil compiled TAG is the derivatization techniques to form methyl esters (Indrasti et al., 2010; Park and Lee, 2003). This approach cannot identify the actual TAG molecule but only calculates the percentage 
of fatty acids from the total TAG fraction (Ruiz-Samblas et al., 2010). Analysis of food adulteration with lard depends on the identification and determination of certain characteristics of the constituents. Analysis of lard with GC was carried out by observing the fatty acids derivatized as methyl esters (Takenaga et al., 2008; Rohman et al., 2012).

\section{Research Methods}

\subsection{Material}

The sample that used was a dog lard from Bantul, Yogyakarta, pork lard, goat lard, chicken lard, wild boar lard and cattle lard. Other materials that used in this research were n-hexane, $\mathrm{NaOCH} 3$ solution $0.2 \mathrm{~N}$, solution of $\mathrm{BF} 3$, saturated $\mathrm{NaCl}$ and anhydrous $\mathrm{Na} 2 \mathrm{SO} 4$ (Rohman and Che Man, 2011; Kumar et al., 2014).

\subsection{Fat extraction}

Dog lard was cutted into small pieces, melted at a temperature of $(90-100)^{\circ} \mathrm{C}$ for approximately one hour in the oven. The melted fat was filtered with flannel, anhydrous Na2SO4 was added and then centrifuged at $3000 \mathrm{rpm}$ for 20 minutes. The oil layer was decanted, filtered with Whatman paper which was placed on anhydrous Na2SO4 (Rohman et al., 2012). The solution was kept in the cupboard ice at $-20^{\circ} \mathrm{C}$ in a rolling test tube. The solution was used for derivatization process.

\subsection{Derivatization}

The fatty acid derivatization aims to convert fatty acids into fatty acid methyl esters using $0.2 \mathrm{~N} \mathrm{NaOCH} 3$ and BF3 solution. The derivatization results containing fatty acid methyl ester (FAME) derivatives were taken and injected into a gas chromatograph system. A total $1 \mu \mathrm{L}$ supernatant was injected into a gas chromatography-mass spectrometry, replication was performed 3 times.

\subsection{Instrumentation System}

A total of $1 \mu \mathrm{L}$ methyl ester was injected into the GC column using a machine autosampler. The separation was done in a column DB1-MS Restech, $30 \mathrm{~m} \times 0.25 \mathrm{~mm}$ ID, $0.25 \mu \mathrm{m}$, with a polymethyl xiloxan stationary phase, injector temperature $230^{\circ} \mathrm{C}$, with the column temperature $70^{\circ} \mathrm{C}$ and raised up to $300^{\circ} \mathrm{C}$ with $10^{\circ} \mathrm{C}$ rise $/$ minute, a flow rate of $1.15 \mathrm{~mL} / \mathrm{min}$. Helium gas mobile phase. The MS detector that used is Electron Multifier Detector (EMD) $70 \mathrm{MeV}$. The results of the analysis was in the form of a mass spectrum compared with the library WILLEY147 \& NIST47 that contained in GC-MS software.

\subsection{Data Analysis}

Data obtained from the GC-MS was in the form of fatty acids methyl esters. The content of fatty acid methyl esters of each lard were grouped by using chemometrics PCA with 16 Minitab.

\section{Result and Discussion}

\subsection{Fat Extraction}

Extraction was carried out to obtain dog fat, extraction through a heating process using an oven with a temperature of $90^{\circ} \mathrm{C}$ with duration 2-2.5 hours. The advantage of this method is that the yield of the extract obtained a lot, easy and inexpensive (Rohman et al., 2012).

The percentage of yield was calculated by comparing obtained dog fat extract with the dog fat weight, thus obtained $14.667 \%$. The results yield is affected by food intake of animals such as the dog itself, fat body parts were taken, and the extraction of fat (Lobb and Chow, 2007). The lipid fraction that obtained then carried out by the esterification process. The esterification reaction aims to transform into a fatty acid methyl ester form (Figure 1). The esterification process is carried out using BF3 as a catalyst. BF3 is an acidic compound (Purbasari and Silviana, 2008). 


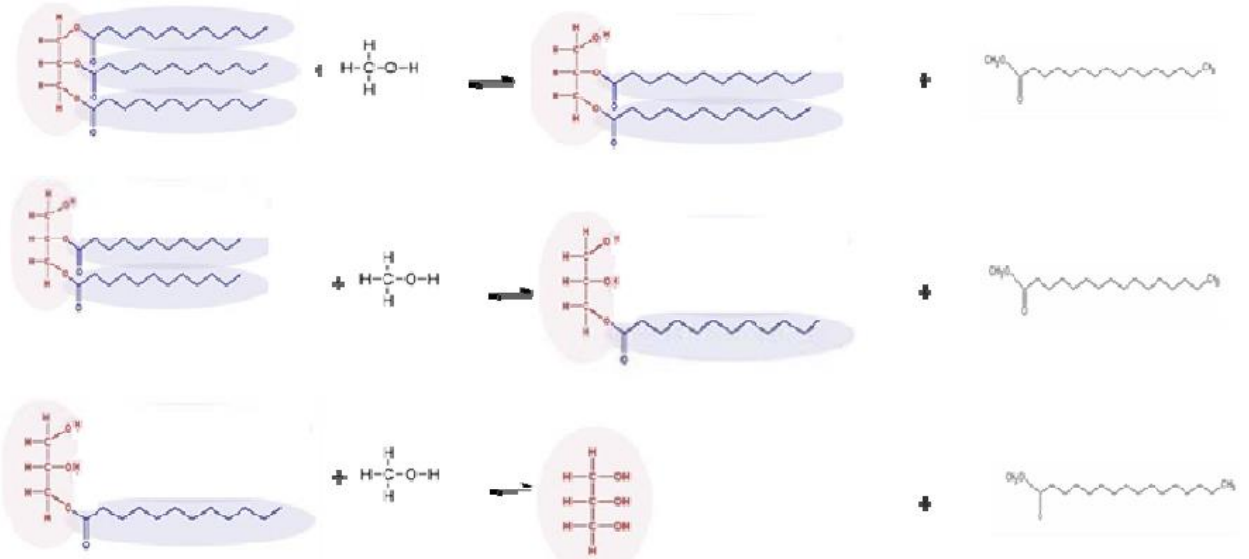

Figure 1. Kinetic transesterification in trigliserida (Silva et al., 2012)

\subsection{The Composition of Fatty Acids in Dogs}

Analysis of dog fatty acids was carried out by gas chromatography-mass spectrometry (GC-MS) method. This instrument is a combination of gas chromatography with mass spectrometer detector. Gas chromatography is used for the separation of fatty acids in the form of methyl esters. In addition to a retention time (tR) of the separation in gas chromatography, there is Similarity Index (SI) to determine the proximity of the chemical structure of the fatty acid types (Table 1). Results SI> 90 showed similarities with the abundance of ion mass spectra of the target / fat samples except oleic acid (89\%).

Table 1. The results of the separation and identification of compounds on dog fats with GCMS

\begin{tabular}{llllll}
\hline Number & $\mathbf{t}_{\mathbf{R}}(\mathbf{m i n})$ & \% Area $\mathbf{E S D}(\mathbf{n}=\mathbf{3})$ & SI & $\mathbf{B M}$ & Compound Name \\
\hline 1 & 15.18 & $1.19 \pm 0.25$ & 97 & 214 & $(\mathrm{C} 12: 0)$ Methyl Lauric \\
2 & 16.96 & $4.33 \pm 0.30$ & 96 & 242 & $(\mathrm{C} 14: 0)$ Methyl Miristate \\
3 & 18.31 & $0.12 \pm 0.02$ & 95 & 256 & (C15:0) Methyl Pentadecanoate \\
4 & 19.46 & $4.60 \pm 0.30$ & 94 & 268 & (C16:1) Methyl Palmitoleate \\
5 & 19.79 & $12.80 \pm 2.90$ & 92 & 270 & (C16:0) Methyl Palmitate \\
6 & 21.80 & $0.13 \pm 0.09$ & 92 & 284 & (C17:0) Methyl Margarat \\
7 & 24.33 & $44.33 \pm 5.22$ & 89 & 296 & (C18:1) Methyl Oleate \\
8 & 25.60 & $14.71 \pm 0.32$ & 94 & 298 & (C18:0) Methyl Stearate \\
9 & 27.78 & $1.29 \pm 0.11$ & 93 & 318 & (C20:4) Arachidonic \\
\hline
\end{tabular}

$$
\text { SI }=\text { Similarity Index; BM = Molecular Weight }
$$

This result indicates that the type of fatty acids or similar targets was in accordance with the comparison spectra. Fatty acid compounds with a tR of 24.33 minutes and SI values of $89 \%$ are similar to comparative compounds with the formula C19H36O2 with $\mathrm{m} / \mathrm{z} 296$. Meanwhile, if in the form of fatty acid, a compound of formula is $\mathrm{C} 18 \mathrm{H} 33 \mathrm{O} 2$. CV values in (\%) areas vary greatly. Fat is a component that is not stable in the presence of light. The results of the analysis with GC-MS showed that oleic acid was the highest constituent of fatty acids in dog fat (44.33\%), followed by stearic acid (14.71\%), palmitic acid (12.80\%), palmitoleic acid (4.60\%), myristic acid (4.33\%), arachidonic acid (1.29\%), lauric acid $(1.19 \%)$, acid margarate $(0.13 \%)$ and pentadecanoic acid $(0.12 \%)$ (Figure 2$)$.

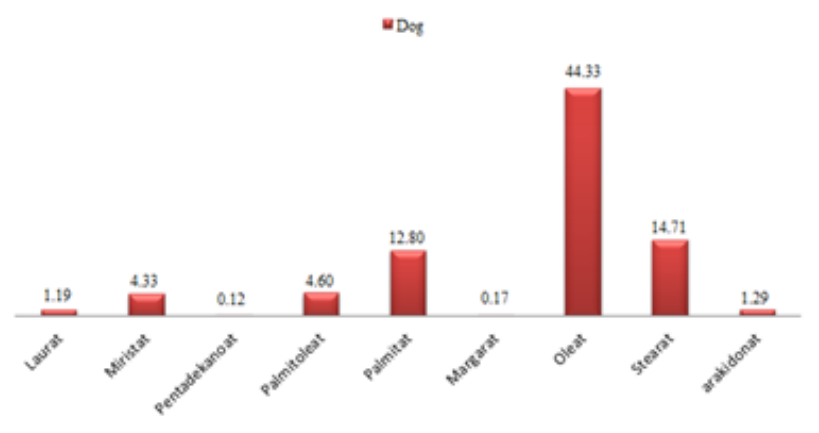

Figure 2. Histogram of a type of fatty acid in dog fat 
Oleic acid is an unsaturated fatty acid with one double bond. When viewed from the bond of unsaturation, dog fat contains many types of saturated fatty acids namely lauric (C12: 0), myristate (C14: 0), palmitate (C16: 0), margarate (C17: 0), and stearic (C18: 0). While unsaturated fatty acids are palmitoleic acid (C16: 1), oleic acid (C18: 1), and arachidonic (C20: 4). If you see the percentage percentage of content, then there are more unsaturated fatty acids (50.22\%) (Figure 3). Saturated fatty acids amount was $33.03 \%$ and $16.75 \%$ was the other content than methyl ester. The amount of unsaturated fatty acid content affect on the physical form of fat at room temperature and the stability of the fat.

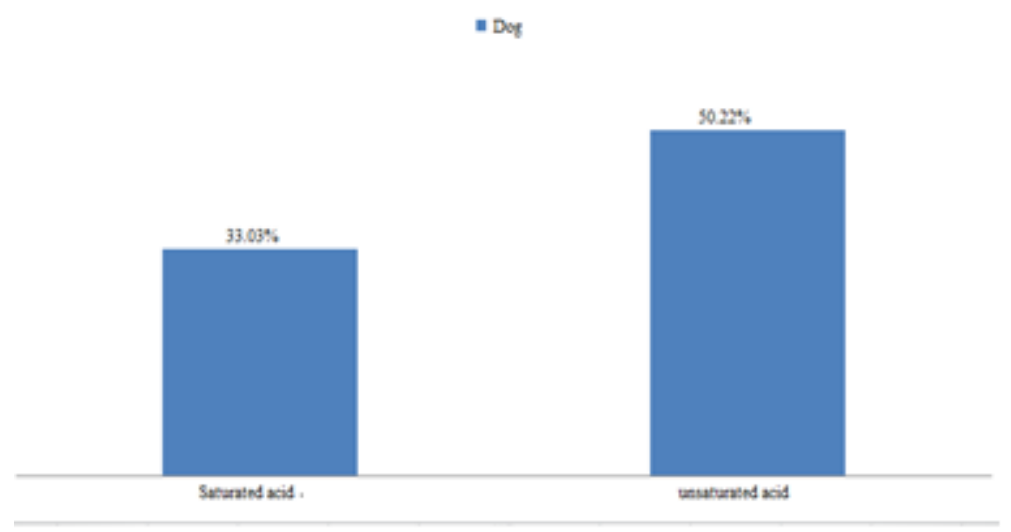

Figure 3. Histogram of saturated fatty acids and not saturated in dog fat

\subsection{Comparison of Dog Fat, Boar, Beef Fat, Lard, Chicken Fat and Goat Fat}

In addition to dog fat, in this study also searched for fatty acids in the form of methyl esters for other animals, namely beef, lard, chicken, and goat fat. Fat collection was the same as for lard extract on the dog fat. The highest oleic acid from meat namely in order were dog fat (48.41\%), chicken (45.60\%), wild boar (45.24\%), lard (39.53\%), goat (21.82\%), and beef $(14.90 \%)$ (Table 2). Oleic acid and palmitoleic acid are included in the unsaturated fatty acids. The highest content of palmitoleic acid in chicken fat (6.88\%), then dog fat (4.42\%), wild boar fat (2.23\%), lard (1.17\%), goat fat $(0.41 \%)$, and beef fat $(0.40 \%)$.

Table 2. The results of the analysis of acid content in dog fat, wild boar, lard, chicken fat, beef fat, and goat fat with GCMS

\begin{tabular}{lllllll}
\hline Methyl ester & \multicolumn{7}{c}{ Percentage (\%) of methyl esters } \\
\cline { 2 - 7 } & Dog & $\begin{array}{l}\text { Wild } \\
\text { Boar }\end{array}$ & Lard & Chick & Beef & Goat \\
\hline Methyl laurate (C12:0) & 1.19 & 0.68 & 1.49 & 0.29 & 0.88 & 0.43 \\
Methyl myristate (C14:0) & 4.37 & 2.0 & 3.19 & 0.68 & 3.84 & 1.79 \\
Methyl pentadekanoate (C15:0) & 0.12 & nd & nd & nd & 0.45 & 0.32 \\
Methyl Palmitoleic (C16:1) & 4.42 & 2.23 & 1.17 & 6.88 & 0.40 & 0.41 \\
Methyl palmitate (C16:0) & 13.00 & 19.65 & 21.01 & 28.98 & 25.70 & 18.00 \\
\hline Methyl margarate (C17:0) & 0.17 & 0.27 & nd & nd & 0.43 & 0.29 \\
Methyl oleate (C18:1) & 48.41 & 45.24 & 39.53 & 45.60 & 14.90 & 21.82 \\
Methyl stearate (C18:0) & 14.71 & 14.37 & 10.03 & 5.20 & 35.03 & 36.68 \\
Methyl arachidonic (C20:4) & 1.29 & nd & nd & nd & nd & nd \\
Methyl arachidate (C21:1) & nd & nd & nd & nd & 0.17 & 0.48 \\
\hline
\end{tabular}

nd $=$ not detected

The highest content of saturated fatty acids were in beef fat $(66.33 \%)$. The other amount of fatty acid are goat fat (57.22\%), wild boar fat (39.39\%), lard (35.71\%), dog fat (33.03\%), and chicken fat (35.15\%) (Figure 4). The highest unsaturated fat content in wild boar fat $(55.91 \%)$, chicken fat $(54.30 \%), \operatorname{dog}$ fat $(50.22 \%)$, lard $(35.72 \%)$, goat fat (22.69\%), and beef fat $(16.51 \%)$. 


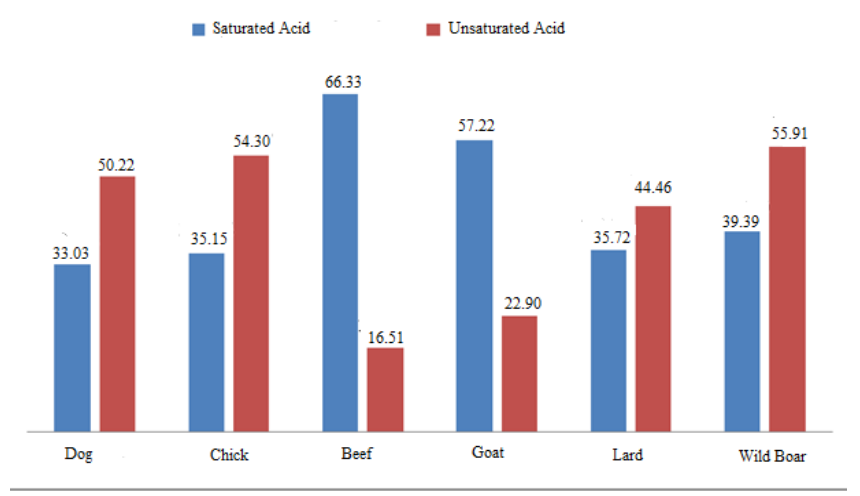

Figure 4. The amount of saturated fatty acids and unsaturated dog fat, lard, chicken fat, beef tallow and mutton fat 3.4 Principal Component Analysis (PCA) Fat Boar and Other Animal Fats

Principal Component Analysis (PCA) is a data interpretation performed by reducing data, in which the number of variables in a matrix is reduced to produce new variables while maintaining the information held by the data. The new variables produced are scores or major components (Rohman, 2012b). PCA aims to classify variables that are correlated with each other and replace them with a new group called the main component (principal component) (Coltro et al., 2005). PCA simplifies data by reducing a number of variables to a smaller number of orthogonal variables. This needs to be correlated between variables. Although PCA reduces the number of initial variables, PCA retains initial variability and information. PCA also helps provide pattern visualization and correlation analysis (Miller and Miller, 2010).

Dogs fat are close to lard (Figure 5). In physical chemistry, dog fat is similar to lard. Guntarti et al (2016) research using GC-MS chromatography lard has physical chemical properties close to chicken fat, and also wild boar fat. So if it can be taken an approach that dog fat chemistry physical properties are close to the physical and chemical properties of lard, chicken fat, and wild boar fat.

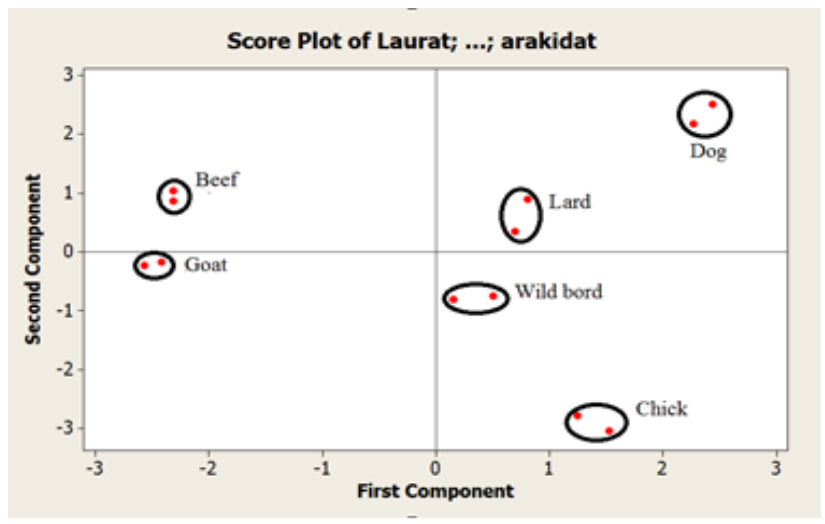

Figure 5. Score of the PCA plot of dog fat, chicken fat, lard, wild boar fat, goat fat and beef fat by using fatty acids as variables

\section{Conclusion}

Based on research results indicate that the fatty acids in dogs by using GC-MS produces 9 types of fatty acids are: lauric $(1.19 \pm 0.25) \%$, myristic $(4.33 \pm 0.30) \%$, pentadekanoat $(0.12 \pm 0.02)$, palmitoleate $(4.60 \pm 0.074) \%$, palmitate $(12.80 \pm$ $2.90) \%$, margarate $(0.13 \pm 0.09) \%$, oleate $(44.33 \pm 5.22) \%$, stearic $(14.71 \pm 0.32) \%$, and arachidonic $(1.29 \pm 0.11) \%$. The total content of unsaturated fatty acids in dogs were $50.22 \%$ and saturated fatty acids were $33.03 \%$. With Chemometrics Principles Component Analysis (PCA) dog fat, wild boar fat, chicken fat, lard, beef fat, and goat fat were grouped.

\section{Acknowledgement}

I would like to thank the LPPT UAD who have been willing to fund this research so that this research can be carried out as well as possible.

\section{References}

Coltro, W. K. T., Ferreira, M. M. C., Macedo, F. A. F., Oliveira, C. C., Visentainer, J. V., Souza, N. E., \& Matsushita, M. (2005). Correlation of Animal Diet and Fatty Acid Content in Young Goat Meat by Gas Chromatography and Chemometrics. Meat Science, 71, 358 -363. https://doi.org/10.1016/j.meatsci.2005.04.016

Grob, R. L. (2004). Theory of Gas Chromatography. dalam: Emeritus, R.L.G.P.D. ()2007. Endogenous biophenol, fatty 
acid and volatile profiles of selected oils. Food Chemistry, 100, 1544-1551.

Guntarti, A., \& Prativi, S. R. (2017). Aplikasi metode fourier transform infrared (FTIR) dikombinasikan dengan kemometrika untuk analisis daging tikus. Pharmasiana, ISSN: 2088 4559; e-ISSN: 2477 0256. 7(2), Nov 2017, Hal. 133-140. https://doi.org/10.12928/pharmaciana.v7i2.4247

Guntarti, A., Martono, S., Yuswanto, A., \& Rohman, A. (2015). FTIR Spectroscopy in Combination with Chemometrics for Analysis of Wild Boar Meat in Meatball Formulation. Asian Journal of Biochemistry, ISSN 1815-9923 / https://doi.org/10.3923/ajb.

Guntarti, A., Rohman, A., Martono, S., \& Yuswanto, A. (2016). Autentikasi Lemak Celeng Dengan Kromatografi Gas Spektrokkopi Massa Yang Dikombinakan Kemometrika PCA (Principle Component Analysis), Prosiding Rakernas dan Pertemuan Ilmiah Tahunan Ikatan Apoteker Indonesia 2016. e-ISSN: 2541-0474.

Indrasti, D., Che Man, Y. B., Mustafa, S., \& Hashim, D. M. (2010). Lard detection based on fatty acids profile using comprehensive gas chromatography hyphenated with time-of-flight mass spectrometry. Food Chemistry, 122, 1273-1277. https://doi.org/10.1016/j.foodchem.2010.03.082

Kealey, D., \& Haines, P. J. (2002). Instant Notes: Analytical Chemistry. Printed by BIOS Scientific Publishers Limited, $26-53$

Kumar, A., Lindley, M. R., \& Mastana, S. S. (2014). A time efficient adaptation of GC-FID method for analysis of PBMC lipid composition. Journal of Biochemistry Technology, 5, 760-764.

Miller, J. N., \& Miller, J. C. (2010). Statistics and Chemometrics for Analytical Chemistry, 6th Edition. Pearson Education Limited: Harlow.

Park, J. R., \& Lee, D. S. (2003). Detection of adulteration in olive oils using triacylgylcerols composition bu high temperature gas chromatography. Bulletin-Korean Chemical Society, 24, 524-530.

Purbasari, A., \& Silviana (2008). Kajian Awal Pembuatan Biodiesel dari Minyak Dedak Padi dengan Proses Esterifikasi. 12(1), 19-21.

Rahayu, W. S., Rohman, A., Martono, S., \& Sudjadi (2018). Application of FTIR Spectroscopy and Chemometrics for Halal Authentication. Indones. J. Chem., 18(2), 376-381. https://doi.org/10.22146/ijc.27159

Rohman, A. (2012). Pengembangan dan Analisis Produk Halal. Pusat Penelitian Produk Halal LPPT UGM: Yogyakarta, $13-40$.

Rohman, A., \& Che Man, Y. B. (2011). The Use of Fourier Transform Mid Infrared (FT-MIR) Spectroscopy For Detection and Quantification of Adulteration in Virgin Coconut Oil. Food Chemistry, 129, 583-588. https://doi.org/10.1016/j.foodchem.2011.04.070

Rohman, A., \& Man, Y. B. C. $\left(2012^{\mathrm{b}}\right)$. The chemometrics approach applied to FTIR spectral data for the analysis of rice bran oil in extra virgin olive oil. Chemometrics and Intelligent Laboratory Systems, 110, 129-134. https://doi.org/10.1016/j.chemolab.2011.10.010

Rohman, A., Kurniawati, E., \& Triyana, K. (2014). Analysis of lard in meatball broth using Fourier transform infrared spectroscopy and chemometrics. Meat Science, 94, 94-98.

Rohman, A., Triyana, K. S., \& Erwanto, Y. $\left(2012^{\mathrm{a}}\right)$. Differentiation of lard and other animal fats based on triacylglycerols composition and principal component analysis. International Food Research Journal, 19(2), 475-479.

Ruiz-Samblas, C., Gonzales-Casado, A., Cuadros-Rodriguez, L., \& Garcia, F. P. R. (2010). Application of selected ion monitoring to the analysis of triacylglycerols in olive by high temterature-gas chromatography/mass spectometry. Talanta, 82, 255-260. https://doi.org/10.1016/j.talanta.2010.04.030

Silva, C., Fabiano, L. A., Cameron, G., \& Seider, W. D. (2012). Optimal Design of an Algae Oil Transesterification Process. Proceedings of the 11th International Symposium on Process Systems Engineering. 15-19 July 2012: Singapore. https://doi.org/10.1016/B978-0-444-59506-5.50007-9

Takenaga, F., Matsuyama, K., Abe, S., Torii, Y., \& Itoh, S. (2008). Lipid and Fatty acid composition of Mesocarp and seed of avocado fruits Harvested at Northern Range in Japan. Journal of Oleo Science, 57, 591-597. https://doi.org/10.5650/jos.57.591

\section{Copyrights}

Copyright for this article is retained by the author(s), with first publication rights granted to the journal.

This is an open-access article distributed under the terms and conditions of the Creative Commons Attribution license (http://creativecommons.org/licenses/by/4.0/). 